Purdue University

Purdue e-Pubs

LARS Symposia

Laboratory for Applications of Remote Sensing

$1-1-1981$

\title{
The Role of Digital Terrain Models in the Remote Sensing of Forests
}

\author{
B. Guindon \\ D. G. Goodenough
}

P. M. Teillet

Follow this and additional works at: http://docs.lib.purdue.edu/lars_symp

Guindon, B.; Goodenough, D. G.; and Teillet, P. M., "The Role of Digital Terrain Models in the Remote Sensing of Forests" (1981). LARS Symposia. Paper 401.

http://docs.lib.purdue.edu/lars_symp/401

This document has been made available through Purdue e-Pubs, a service of the Purdue University Libraries. Please contact epubs@purdue.edu for additional information. 
Reprinted from

\title{
Seventh International Symposium
}

\author{
Machine Processing of
}

Remotely Sensed Data

with special emphasis on

\section{Range, Forest and Wetlands Assessment}

\author{
June 23 - 26, 1981 \\ Proceedings
}

\author{
Purdue University \\ The Laboratory for Applications of Remote Sensing \\ West Lafayette, Indiana 47907 USA
}

\section{Copyright (C) 1981}

by Purdue Research Foundation, West Lafayette, Indiana 47907. All Rights Reserved.

This paper is provided for personal educational use only, under permission from Purdue Research Foundation.

Purdue Research Foundation 
THE ROLE OF DIGITAL TERRAIN MODELS IN THE REMOTE SENSING OF FORESTS

\author{
B, GUINDON, D.G, GOODENOUGH, P.M. TEILLET \\ Canada Centre for Remote Sensing \\ Ottawa, Canada
}

ABSTRACT IN LIEU OF MANUSCRIPT

\section{ABSTRACT}

Approximately one half of Canada's marketable forests are located in mountainous areas. If this vital resource is to be monitored using high resolution satellite and airborne sensors, topographic information must be incorporated into image analysis procedures.

For the past two years, research has been on-going at the Canada Centre for Remote sensing into the integration of digital terrain models with imagery for the purposes of estimating timber volume and energy. This paper describes the principal components of our processing scheme with particular emphasis on the use of elevation, slope and aspect data.

Imagery is first rectified to a map grid with the aid of a digital elevation model (DEM) (Guindon et al. 1980, Teillet et al. 1980). Corrected imagery is desirable as both topographic and auxiliary information are map based.

The DEM and sensor flight path parameters can also be used to generate masks which accurately delineate areas of shadow and layover. Such areas can be extensive on both airborne and satellite SAR imagery and must be excluded from further analysis.

Terrain data has been incorporated in the image classification process in two ways:

a) Elevation, slope and aspect have been found to be useful features in forest specie discrimination and have, therefore, been treated as additional features in maximum likelihood classification. b) Masks have been used to improve class statistics by eliminating corrupted pixels, such as shadow and SAR layover pixels, and to limit image areas over which classification is carried out.

Finally, the timber volume for an area covered by imagery can be estimated with the aid of the classified image if the average timber volume per unit ground surface area is known for each class. In mountainous areas, problems can arise because the two dimensional image projection of the terrain does not accurately reflect the total ground surface extent. This can be overcome by applying a pixel correction factor based on surface slope information.

\section{REFERENCES}

Guindon, B., J.W.E. Harris, P.M. Teillet, D.G. Goodenough and J.-F. Meunier, 1980 , "Integration of MSS and SAR Data of Forested Regions in Mountainous Terrain", Proceedings of the Fourteenth International Symposium of Remote Sensing of Environment, San Jose, Costa Rica, P. 1673 .

Teillet, P.M., B., Guindon, and D.G. Goodenough, 1980, "Integration of Remote Sensing Data Sets by Rectification to UTM Coordinates With the Use of Digital Terrain Models", Proceedings of the Fourteenth Congress of the International Society for Photogrammetry, Hamburg, West Germany . 